Logos Universality Mentality Education Novelty: Economics and Administrative Sciences

ISSN: 2284-5984 | e-ISSN: 2501-0425

Covered in: ERIH+; CEEOL; Index Copernicus; CrossRef; CrossCheck; J-Gate; Google Scholar; Ideas RePeC;

Econpapers; Socionet; KVK; WorldCat, EBSCO.

2021, Volume 6, Issue 1, pages: 45-56 | https://doi.org/10.18662/lumeneas/6.1/28

\section{Micro-study on Telework Activity}

\author{
Alunica MORARIU ${ }^{1}$ \\ ${ }^{1}$ Associate Professor PhD, "Stefan cel \\ Mare" University of Suceava, Romania, \\ alunica.morariu@gmail.com
}

\begin{abstract}
This paper is a micro-study on telework activity, the author wanting to highlight certain aspects of this form by which today's employees can perform their own tasks that they perform in order to obtain salaries. Starting from the economic meaning of the concept of "work", we come to the presentation of some advantages and disadvantages that appear, the institutional framework applicable to telework in Romania is adequately treated, resorting to some quantitative or qualitative approaches. The investigations also reveal, in addition to benefits for employees and employers, some risks regarding data protection and surveillance systems, difficulties arising from living in apartments with large family members, high and unforeseen costs, etc.
\end{abstract}

Keywords: work versus telework; technical progress; IT requirements; institutional framework; legislation.

How to cite: Morariu, A. (2021). Micro-study on Telework Activity. Logos Universality Mentality Education Novelty: Economics and Administrative Sciences, 6(1), 45-56 https://doi.org/10.18662/lumeneas/6.1/28 


\section{The economic meaning of the concept of "work"; the step towards telework}

The notion of work has various meanings. According to DEX (Explanatory Dictionary of the Romanian Language), work is "the pursuit of a physical or intellectual activity aimed at a particular purpose «or» activity by which man modifies and adapts things in nature to meet his needs «on» conscious activity (specific to man) directed towards a certain purpose, in the process of which man performs, regulates and controls by his action the exchange of matter between himself and nature for the satisfaction of his needs «on» physical or intellectual activity aimed at creating material and spiritual goods" (DEX.online, 2016).

Things being clear in this regard, Economic Science (Political Economy) considers that work is "a conscious activity (specific to man) aimed at a certain purpose, in the process of which man performs, regulates and controls by his action the exchange of matter between himself and nature to meet his needs" (UTJ, 2021). Obviously, political economy approaches work a determining factor in production (primary factor, origin of production), devoting large spaces to it, in terms of scientific approach. Some economists, namely those considered classics of political economy (Adam Smith, David Ricardo or Jean Baptiste Say), argue that wealth (wealth) is the result of the process of productive labor and, consequently, the wealth of a nation depends directly on labor productivity. (Moldovan, 2020).

Productivity is reflected in the ratio between the amount of production obtained and the amount of labor used (Bostan, 1999, 2006; Burciu, 2008). In the case of a given production function and an optimal combination ratio, we expect to have a constant between the amount of factors used (labor, land, capital) and the amount of production achieved. Professor Mircea Coşea explains: "In reality, over an average period of time, there is an increase in the amount of products, although a constant amount of production factors are used (...)" (Coşea, 2019).

That increase must be attributed to the technical progress introduced. It can be categorized according to the action it has on the factors of production, as follows:

"(i) labor saving - determines a reduction of labor consumption by increasing the capital consumption necessary for the modernization and improvement of machines and equipment;

(ii) capital saving - determines a reduction of capital consumption by increasing the quality and classification of work; 
(iii) neutral - acts on both labor and capital. It is specific to the increase of production through a superior initial endowment both at the technical and human level" (Coşea, 2019).

The last decades - related to the 3rd category of technical progress know the intervention of the computer (computerization) in the work processes. Although slower at first, nowadays "many companies invest in modern equipment and information technology solutions through taking advantage of the technological advances of the 21st century. The former have the function of increasing production capacity and labor productivity. The software is an important element that allows the integration of each of the business sectors, work planning and management." (STOLCAD, 2019).

In general, we can talk separately about the endowment with IT resources related to the production lines (Figure 1) and those necessary for the managerial activity of the companies, with all the sub-activities that this implies.

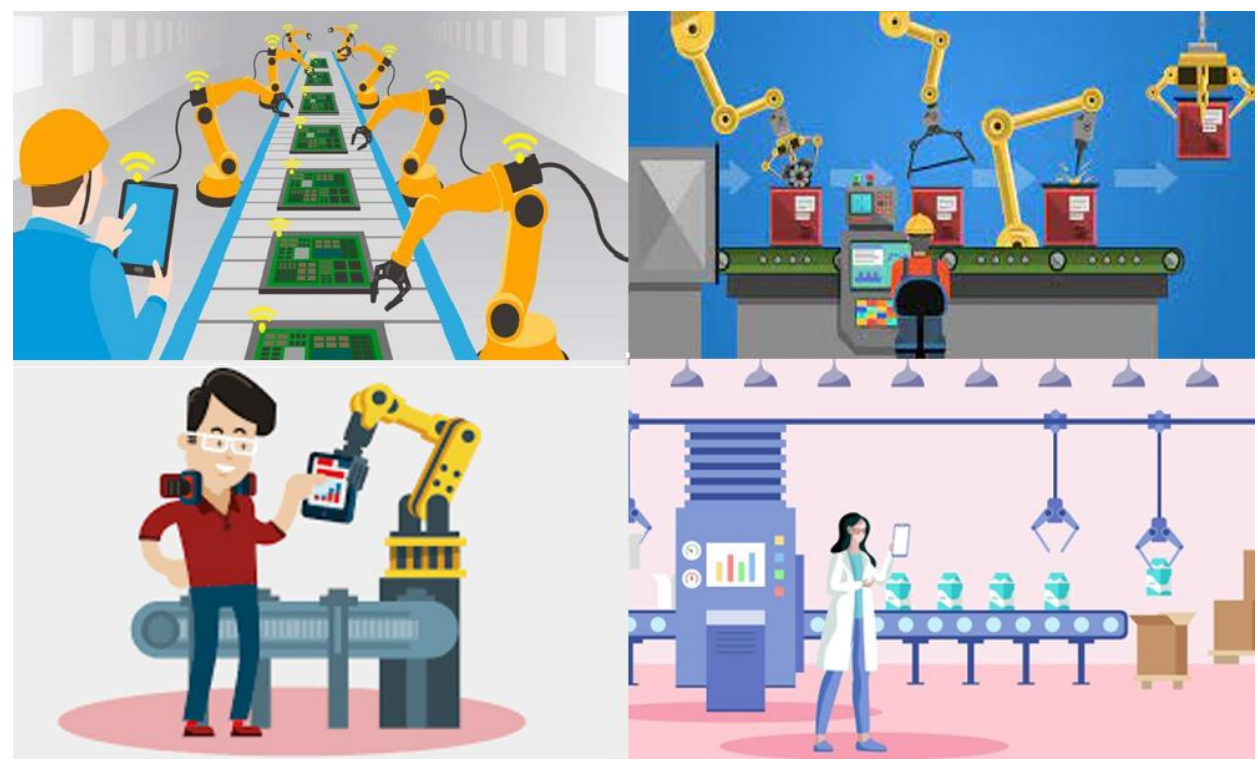

Figure 1. Schematic representations of computer use in various production processes

Source: Processing of the author from: Technosam.ro (n.d.), SeniorSoftware (n.d.), KMOUpgrade.de (n.d.), Ciel.ro (n.d.)

We note that this paper aims to address the issue of telework, especially from the perspective of workers, labor relations and the current institutional framework, with reference to the Romanian economic and social space. This, in the context in which from the great diversity of 
professions/trades existing at present (Figure 2), a certain weight is suitable for the online performance of their activity in relation to employers.

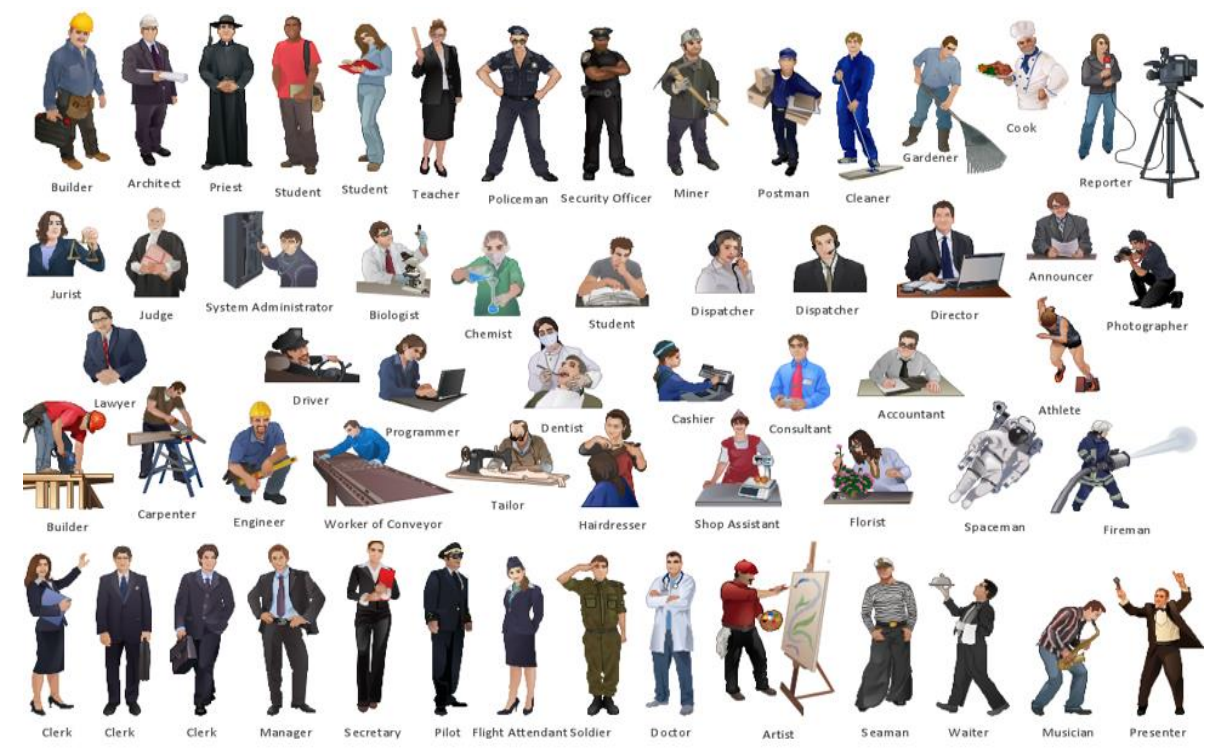

Figure 2. Diversity of professions/occupation at present

Processing by the author from: Spanish to English Idioms. (n.d.)

The definition given to telework is "the form of work organization by which the employee, on a regular and voluntary basis, fulfills his duties specific to the position, occupation or trade he holds, in a place other than the work organized by the employer, at least one day on the moon, using information and communications technology" (Romanian Parliament, 2018).

Obviously, looking at the literature, we note that this "form of distance work has emerged and developed as a result of the need to find a solution for transporting workers to / from work in the context of urban traffic congestion, information technology and communications being a means by which the physical presence of the worker at the classic workplace organized by his employer can be supplemented." (Dima, 2020). If two decades ago it was a favorite practice in consulting or IT, 5-6 years ago telework took on another dimension, approx. $17 \%$ of the population of the European Union being engaged in work at home or in telecentres, in coworking spaces (Destepti.ro, 2020).

At the EU level, the areas with the highest rates of employees working from home during the Covid-19 pandemic were: education, financial services and public administration (Figure 3). 


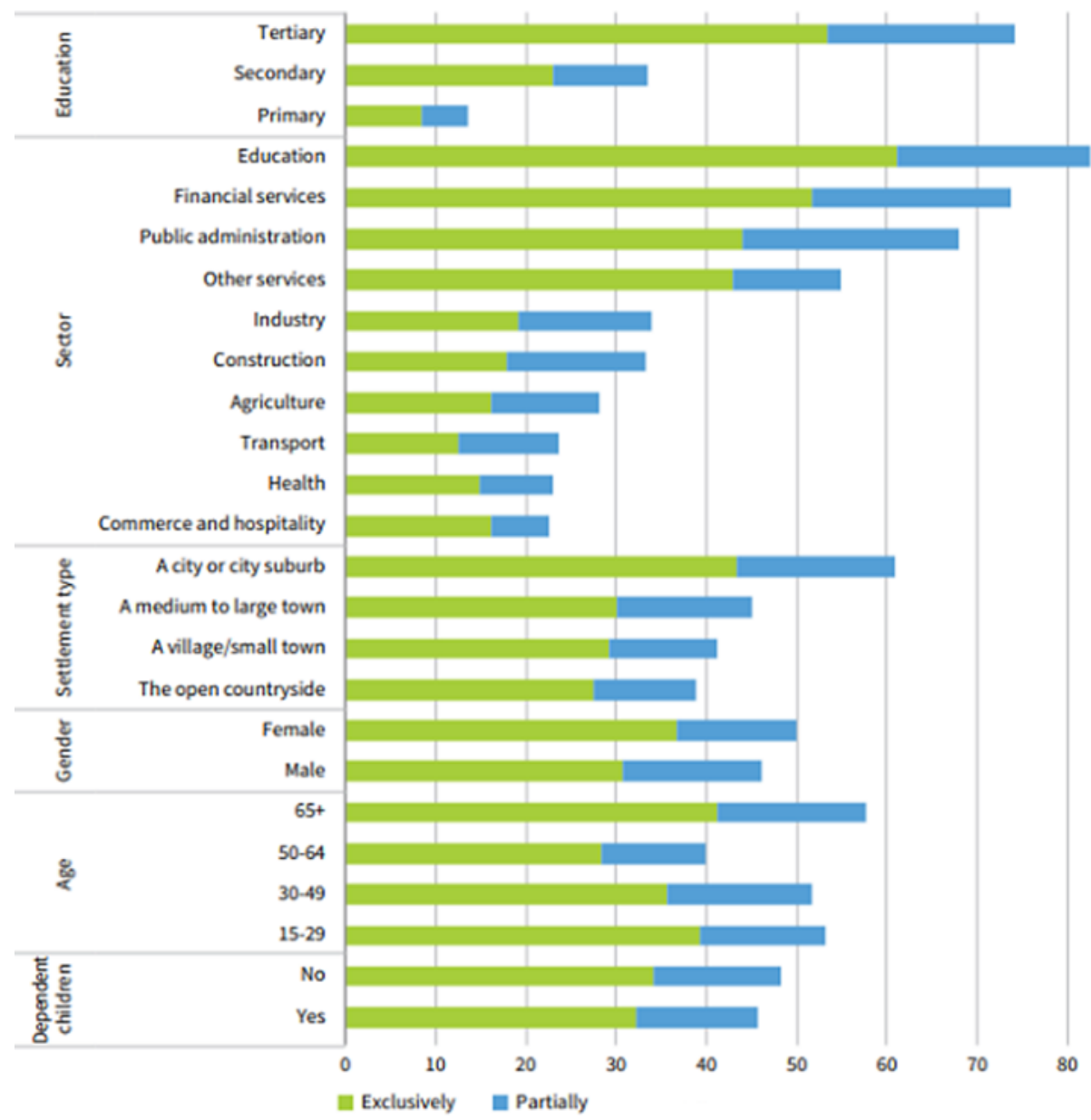

Figure 3. Telework within the European Union (27) during the Covid-19

$$
\text { pandemic }(\%)
$$

Source: Bechir (2020)

In the United States (Figure no. 4), in 2010, work from home is officially recognized when the Telework Enhancement Act comes into force, which requires companies to establish policies for teleworking. Here, "between 2005 and 2015, the number of people working from home increased by $115 \%(\ldots)$, and $56 \%$ of existing jobs in the US can be compatible with teleworking" (UCMS, 2020). 


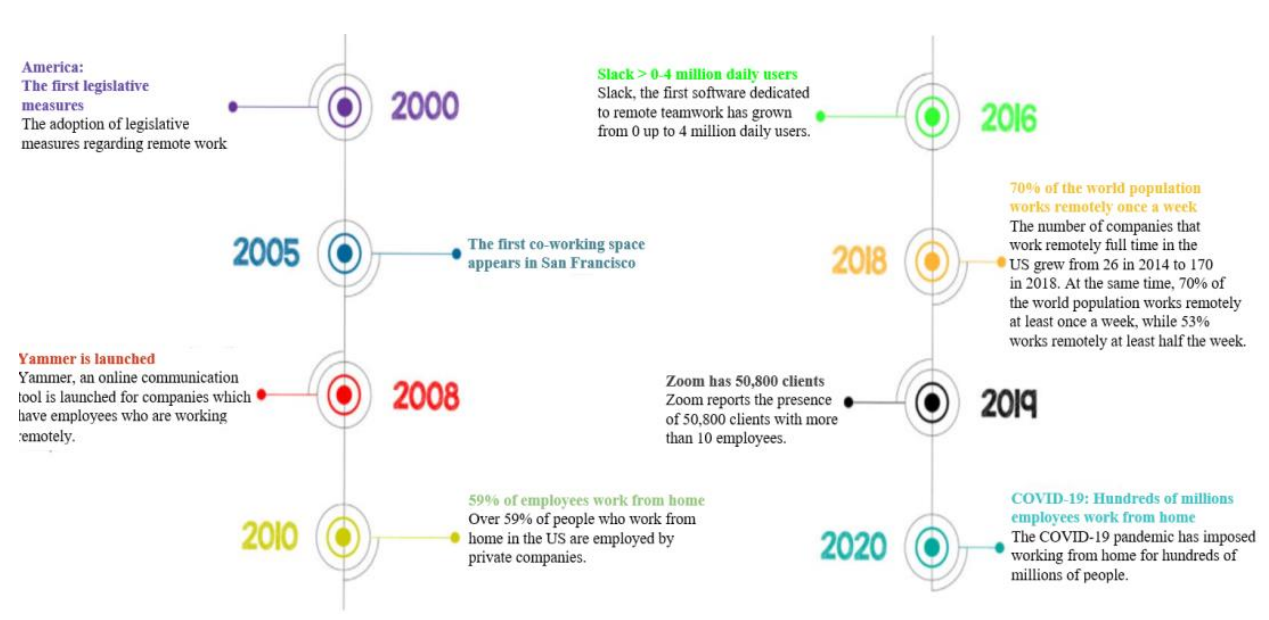

Figure 4. Moments in the evolution of telework

Source: UCMS (2020)

As it is generally known, crisis situations favor this type of activity, in the sense of its appreciable expansion. If we refer to the national space, in the conditions of the current pandemic crisis, "the provision of telework work was no longer a possibility, but an obligation of the parties to the employment relationship. By way of derogation from the voluntary nature of telework and from the principle of autonomy of will of the parties to the employment relationship, during the state of emergency, public and private sector employers had the obligation to introduce by unilateral act, where possible, work at at home or in telework" (Duca, 2021).

Thanks to IT means (minimal, a laptop and a very good Internet connection), switching employees to telework generates a number of advantages for them. It is mainly about the possibility of avoiding congested traffic, working in a favorite space, next to family members, arranging the schedule according to their own preferences, possibly it can be discussed and a lower stress than in the case of classic work. For the employer, "administrative costs for renting space, utility costs, fuel consumption, and fleet will be reduced.” (Romanian Parliament, 2017).

\section{Creating and improving the institutional framework for facilitating telework in Romania}

Two decades have passed since a European Framework Agreement on Teleworking was concluded between the social partners (European Commission, 2002) - "a form of organizing and/or performing tasks, using information technology, in the context of an employment contract an 
employment relationship, in which the activity that could also be carried out at the employer's premises/premises, is regularly carried out outside the respective premises/premises"(Romanian Parliament, 2017). Subsequently, the social partners agreed that "teleworking is both a means for companies to modernize their work organization and a means for employees to reconcile work and social life"(Romanian Parliament, 2017).

According to national labor law, the individual contract of employment refers, inter alia, in particular to the place of work, which means "place of employment, located in the premises of the undertaking and / or establishment, including any other place in the area of the undertaking and / or establishment to which the worker has access during the course of his activity."(Romanian Parliament., 2006). But "The Labor Code also provides for the possibility of working from home with a work contract at home. The main peculiarity of this employment contract is that the duties are performed at the employee's domicile, the place of work being in this situation his domicile" (Romanian Parliament, 2017).

What must be acknowledged is that telework is a tool for companies to modernize their work organization, and for employees a valuable tool to reconcile work and social life. However, the employer has a number of obligations:

"(i) to provide the means of information and communication technology and / or secure work equipment necessary for the performance of the work, unless the parties agree otherwise;

(ii) install, inspect and maintain the necessary work equipment, unless the parties agree otherwise;

(iii) provide conditions for the employee to receive sufficient and appropriate training in occupational safety and health, in particular in the form of information and work instructions, specific to the place of work and the use of display screen equipment : to hire, to change the place of work, to introduce new work equipment, to introduce any new working procedure." (Romanian Parliament, 2017).

As the Labor Code was amended, the obligation of teleworkers to respect the confidentiality of the documents used and, in general, what is a trade secret was introduced.

By Government Emergency Ordinance no. 192/2020 for the amendment and completion of Law no. 55/2020 on some measures to prevent and combat the effects of the COVID-19 pandemic, as well as to amend letter a) in art. 7 of Law no. 81/2018 on the regulation of telework activity, it was stated that "During the state of alert, employers dispose by unilateral act, work 
at home or telework, where the specificity of the activity allows." (Figure 6); then it is also "established the obligation of employers to organize their economic activities during the Covid pandemic 19 by using work at home and telework in all situations where the activity allows it. Also, for the employers with more than 50 employees, the obligation is established to organize individualized work programs so as to ensure a good sufficient time interval between the beginning and the end of the work program in order to reduce the social contacts between the employees." (Romanian Government, 2020).

\section{Working remotely}

$>$ During the state of alert, employers dispose by unilateral act, work at home in compliance with the lans in force;

$>$ It can be used only for the activities that involve the use of information and communication technology;

$>$ The decision will contain, in addition to the general elements and the following elements provided by art. 5, paragraph (2) of Lan. no. $81 / 2018$ on the regulation of telenork activity:

- the express specification that the employee works in telework regime

- the period and / or days in which the teleworker carries out bis activity in a job organized by the employer;

- the place / places of carrying out the telework activity agreed by the parties;

- the program in which the employer is entitled to verify the activity of the teleworker and the concrete way of performing the control;

- the way of bighlighting the working hours submitted by the teleworker;

- the responsibilities of the agreed parties according to the place / places of carrying out the telenork activity, including the responsibilities in the field of safety and bealth at work;

- the obligation of the employer to ensure the transport to and from the place where the telework activity is carried out, of the materials that the telenorker uses in his activity, as the case may be;

- the measures taken by the employer so that the telemarketer is not isolated from the rest of the employees and which ensures bim the possibility to meet with colleagues regularly;

- the obligation of the employer to inform the employee regarding the provisions of the legal regulations of the applicable collective labor agreement and / or the internal regulation regarding the protection of personal data, as well as the employee's obligation to comply with these provisions;

- the conditions under which the employer bears the expenses related to the telenork activity.

Figure 5. Rules in case of adoption of the telework work formula, during the alert state (Covid 19) (IM, 2020)

\section{Remote work, a dimensional approach for Romania}

Prior to the pandemic, the number of teleworkers in Romania amounted to 13,835 people, reaching more than 53,000 in March 2020 (Figure 5). "The end of 2020 shows a record number of employees in telecommuting: over 300,000 in the private sector and over 31,000 in the state, in a dynamic that indicates a potential permanent adoption of this style of work" (Deacu, 2021). 


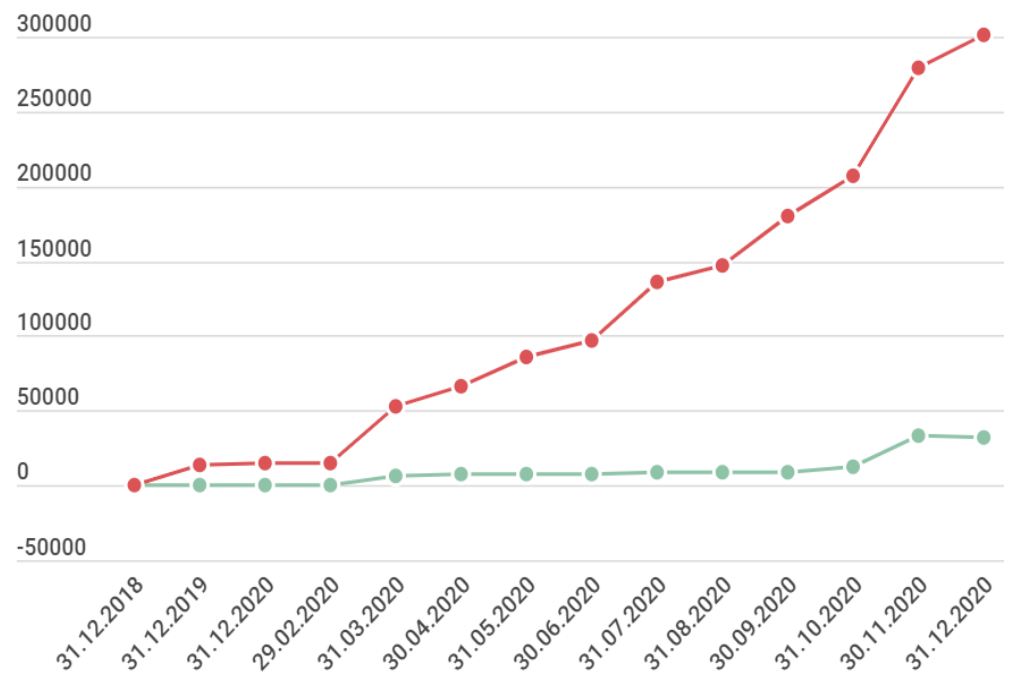

Figure 6. The number of employees with telework contracts (Deacu, 2021)

According to a Eurofound survey, during the pandemic period (June-July 2020), the proportion of teleworkers exclusively in Romania was just over $20 \%$, one of the lowest in the EU (...). However, in some sectors, the share of remote workers was much higher than the national average of $30.1 \%$. For example, during the pandemic, $50 \%$ of companies in the business service surveyed used "full-time telework, while $45 \%$ used hybrid models." (Samek Lodovici et al., 2021).

Referring to the results of other investigations carried out in 2020 by PWC and the National Institute of Administration, it is also shown that " $74 \%$ of the companies in the financial sector surveyed", "over $50 \%$ of executive and management staff in the public sector" used telework, and about 30\% used hybrid models. On the other hand, teleworking in the logistics $(26 \%)$ and pharmaceutical (24\%) companies surveyed was below the national average (Samek Lodovici et al., 2021).

These studies also reveal, in addition to the benefits for employees and employers, some risks regarding data protection and surveillance systems, difficulties arising from living in apartments with large family members, high and unforeseen costs, etc.

\section{Conclusion}

Remarkable developments in the field of information and communication technology make it much easier for teleworkers to carry out their daily remote activities. 
Approaching the issue of telework, especially from the perspective of workers, labor relations and the current institutional framework, with reference to the Romanian economic and social space, allows us to conclude that the advantages that appear are multiple and secondary to possible disadvantages. The benefits of this form of work have shown their value during the Covid-19 pandemic crisis.

Thanks to IT requirements (minimum a laptop and a very good Internet connection), the transition of employees to telework generates important facilities for employees, being mainly about the possibility of avoiding crowded traffic, working in a favorite space, next to family members, arranging the schedule according to one's own preferences may possibly be considered less stress than in the case of classical work.

Therefore, in our opinion, employing companies, but also public institutions, should be encouraged to invest heavily in equipment and training/refresher courses in order to give greater dimensions - quantitative and qualitative - to telework, regardless of whether the pandemic crisis will end sooner or later.

\section{References}

Bechir, M. (2020, December 13). Eurofound: Telemunca - revoluția tăcută ce se desfăşsoară in UE. Creștere spectaculoasă și în România [Eurofound: Telework - the silent revolution taking place in the EU. Spectacular growth in Romania as well]. Cursdeguvernare. https://cursdeguvernare.ro/eurofound-telemuncarevolutia-tacuta-ce-se-desfasoara-in-ue-crestere-spectaculoasa-si-inromania.html

Bostan, I. (1999). Recompensarea factorului muncă [Rewarding the labor factor]. Media Tech.

Bostan, I. (2006). Managementul recompensei [Reward management]. "Ştefan cel Mare" University Publishing House.

Burciu, A. (coord.). (2008). Introducere in management [Introduction to management]. Economică.

Ciel.ro. (n.d.). Soft gestionare industria alimentara [Food industry management software]. https://ciel.ro/soft-productie-alimentara/

Coşea, M. (2017). Manual de economie politică [Handbook of Political Economy University Course]. https://www.academia.edu/30164487/Economie_Politica

Deacu, E. (2021, April 8). Câți angajați din România lucreåă oficial din telemuncă [How many employees in Romania officially work from telework]. Economedia.ro. https://economedia.ro/exclusiv-cati-angajati-din-romanialucreaza-oficial-din-telemunca.html\#.Ye8D1 tBxPa 
Destepti.ro. (2020). Munca la distanță, în timpul pandemiei COVID-19 - 7 metode pentru a fi eficienti [Remote work during the COVID-19 pandemic - 7 methods to be effective]. https://destepti.ro/telemunca-munca-la-distanta-in-timpulpandemiei-covid-19-7-metode-pentru-a-fi-eficienti.

DEX.online. (2016). Muncă [Labor]. In Explanatory Dictionary of the Romanian Language. https://dexonline.ro/definitie/munc $\% \mathrm{C} 4 \% 83$

Dima, L. M. (2020, December 28). Telemunca în sectorul public din România, o măsură excepțională care se impune a deveni regulă? [s the tele-working in the Romanian public sector an exceptional measure which is required to become a rule?]. Revista Romana de Jurisprudenta (Universul Juridic), 4. https://lege5.ro/gratuit/gm4tonzzge3a/telemunca-in-sectorul-public-dinromania-o-masura-exceptionala-care-se-impune-a-deveni-regula-is-the-teleworking-in-the-romanian-public-sector-an-exceptional-measure-which-isrequired-to-become-a-rul

Duca, M. V. (2021). Evoluții ale conceptului de flexicuritate în materia telemuncii [Evolutions of the concept of flexicurity in the field of telework]. Revista Dreptul (Uniunea Juristilor), 7. https://lege5.ro/Gratuit/ha2tembxgyzq/evolutii-ale-conceptului-deflexicuritate-in-materia-telemuncii

European Commission. (2002.) Framework Agreement on Telework. https://www.worker-participation.eu/EU-SocialDialogue/Interprofessional-ESD/Outcomes/Frameworkagreements/Framework-agreement-on-telework-2002

IM. (2020). Ghidul privind desfăşurarea activitătii în regim de muncă la domiciliu/telemuncă/program individualizat de muncă, elaborat de Inspecția Muncii [Guidance on work at home/telework/individualized work schedule, developed by the Labor Inspectorate]. https://www.inspectiamuncii.ro/documents/66402/201782/GHID+PRI VIND+MUNCA+LA+DOMICILIU+_I+TELEMUNCA Legislatie_Op erareRevisal Final3.pdf/9e271cd3-1fd7-43bd-ab37-03648dee1740

KMOUpgrade. (n.d.). Exact voor Productie[Exact for Production]. http://www.kmoupgrade.be/exact-online/productie/

Moldovan, B. (2020). Economie Politică [Political economy - University course]. Babes Bolyai University, Cluj-Napoca.

https://moodle.fspac.ubbcluj.ro/pluginfile.php/65351/course/overview fil es $/$ suport $^{2} 202$ curs $\% 20$ economie $\% 20$ politica $\% 20$ ID.pdf?forcedownload $=1$

Romanian Government. (2020, November 6). Ordonanța de urgență nr. 192/2020 pentru modificarea şi completarea Legii nr. 55/2020 privind unele măsuri pentru prevenirea şi combaterea efectelor pandemiei de COVID-19, precum şi pentru modificarea lit. a) a art. 7 din Legea nr. 81/2018 privind reglementarea activităţii de telemuncă [Emergency Ordinance no. 192/2020 for the amendment and completion of Law no. 55/2020 on some measures 
to prevent and combat the effects of the COVID-19 pandemic, as well as to amend letter a) in art. 7 of Law no. 81/2018 on the regulation of telework activity]. Monitorul Oficial, 1042.

https://legislatie.just.ro/Public/DetaliiDocumentAfis/232731

Romanian Parliament. (2006, July 26). Legea nr.319/2006 a securităţii şi sănătății în muncă [Law no. 319/2006 on safety and health at work]. Monitorul Oficial, 646. https://legislatie.just.ro/Public/DetaliiDocument/73772

Romanian Parliament. (2017). Expunere de motive la Proiectul Legii privind reglementarea activității de telemuncă [Draft Law on the Regulation of Telework]. http://www.cdep.ro/pls/proiecte/upl pck2015.proiect?idp $=16588$

Romanian Parliament. (2018, April 2). Legea nr. 81/2018 privind reglementarea activității de telemuncă [Law no. 81/2018 on the regulation of telework activity]. Monitorul Oficial, 296.

http://legislatie.just.ro/Public/DetaliiDocument/199418

Samek Lodovici, M. et al. (2021). The impact of teleworking and digital work on workers and society.

https://www.europarl.europa.eu/RegData/etudes/ATAG/2021/662907/ IPOL ATA(2021)662907 EN.pdf

SeniorSoftware. (n.d.). Industria 4.0 - revolutia digitala in productie [Industry 4.0 - the digital revolution in production].

https://www.seniorsoftware.ro/industrializarea-4-0

Spanish to English Idioms. (n.d.). Vocabulary list of jobs in Spanish and English. http://spanishtoenglishidioms.blogspot.com/2017/03/vocabulary-list-ofjobs-in-spanish-and.html

STOLCAD. (2019). Trenduri: Informatizarea întreprinderii [Trends: Computerization of the enterprise]. https://www.stolcad.com/files/articles/informatizareaintreprinderii.pdf

Technosam. (n.d.). Avantajele automatizarii procesului de productie [The advantages of automating the production process]. https://technosam.ro/avantajeleautomatizarii-procesului-de-productie/

UCMS. (2020, August 13). Cum a evoluat telemunca? Istoric si context [How has telework evolved? History and context]. https://truehr.ro/cum-a-evoluat-telemunca

UTJ. (2021). Manual de microeconomie [Microeconomics Handbook http:// ec.utgjiu.ro/wp-content/uploads/2021/04/Microeconomie.pdf 